\title{
Taxation and Budget Reform Commission (TBRC) Constitutional Amendment 7: Religious Freedom ${ }^{1}$
}

Rodney L. Clouser ${ }^{2}$

This amendment was removed from the November 2008 ballot by the Florida Supreme Court. FE746 will be maintained on the EDIS website through December 31, 2008, and then archived for historical purposes.

A series of 16 fact sheets has been written on statutory and constitutional proposals adopted by the Taxation and Budget Reform Commission (TBRC). The publications in this series can be accessed at http://edis.ifas.ufl.edu. Fact sheets FE733 through FE741 address statutory changes and fact sheets FE742 through FE748 address constitutional amendments. These fact sheets should not be considered as an all-inclusive assessment of the statutory or constitutional changes recommended by the Taxation and Budget Reform Commission. Some details of proposed changes may not have been discussed due to space limitations. These fact sheets are not intended as a replacement for personal knowledge about actual or proposed changes but are a guide to inform the public on the issues.

\section{Introduction}

According to Article XI, Section 6 of the Florida Constitution, "Beginning in 2007 and each twentieth year thereafter there shall be established a taxation and budget reform commission." The Taxation and Budget Reform Commission (TBRC) is charged with the following:
examine the state budgetary process, the revenue needs and expenditure processes of the state, the appropriateness of the tax structure of the state, and governmental productivity and efficiency; review policy as it relates to the ability of state and local government to tax and adequately fund governmental operations and capital facilities required to meet the state's needs during the next twenty-year period; determine methods favored by the citizens of the state to fund the needs of the state, including alternative methods for raising sufficient revenues for the needs of the state; determine measures that could be instituted to effectively gather funds from existing tax sources; examine constitutional limitations on taxation and expenditures at the state and local level; and

1. This is EDIS document FE746, a publication of the Food and Resource Economics Department, Florida Cooperative Extension Service, Institute of Food and Agricultural Sciences, University of Florida, Gainesville, FL. Published July 2008. Please visit the EDIS website at http://edis.ifas. ufl.edu.

2. Rodney L. Clouser, professor and extension public policy specialist of the Food and Resource Economics Department, Florida Cooperative Extension Service, Institute of Food and Agricultural Sciences, University of Florida, Gainesville, FL.

The Institute of Food and Agricultural Sciences (IFAS) is an Equal Opportunity Institution authorized to provide research, educational information and other services only to individuals and institutions that function with non-discrimination with respect to race, creed, color, religion, age, disability, sex, sexual orientation, marital status, national origin, political opinions or affiliations. U.S. Department of Agriculture, Cooperative Extension Service, University of Florida, IFAS, Florida A. \& M. University Cooperative Extension Program, and Boards of County Commissioners Cooperating. Larry Arrington, Dean 
review the state's comprehensive planning, budgeting and needs assessment processes to determine whether the resulting information adequately supports a strategic decision-making process.

The TBRC can make statutory recommendations to the Florida Legislature and directly place proposed constitutional amendments on the ballot for approval or rejection by Florida voters.

Fact sheets in this series will present information on constitutional amendments the TBRC has placed on the fall 2008 general election (2008 November presidential election) ballot. The commission was charged with holding public meetings to carry out their responsibilities and has been meeting since March of 2007. The committee concluded their work and transmitted their proposed constitutional amendments to the Florida Secretary of State on April 28, 2008. All the proposed constitutional amendments required an affirmative vote of at least two-thirds of the voting members of the commission (17 members). In total, the TBRC approved eleven constitutional proposals. The committee combined these eleven proposals into seven constitutional amendments. The amendments passed by the TBRC will be numbered Amendments 3 through 9 on the fall ballot (Amendments 1 and 2 are reserved for two other 2008 amendment proposals, one approved by the legislature and the other a citizen initiative).

The TBRC amendments placed on the 2008 general election ballot are listed by ballot title below:

- Amendment 3: Changes and Improvements Not Affecting the Assessed Value of Residential Real Property

- Amendment 4: Property Tax Exemption of Perpetually Conserved Land; Classification and Assessment of Land Used for Conservation

- Amendment 5: Eliminating State Required School Property Tax and Replacing with Equivalent State Revenues to Fund Education

- Amendment 6: Assessment of Working Waterfront Property Based upon Current Use
- Amendment 7: Religious Freedom

- Amendment 8: Local Option Community College Funding

- Amendment 9: Requiring 65 Percent of School Funding for Classroom Instruction; State's Duty for Children's Education

Each fact sheet in this series will provide details regarding one of the amendments, submitted to the Secretary of State, in the order they will appear on the ballot (Amendment 3, Amendment 4, Amendment 5, Amendment 6, Amendment 7, Amendment 8, and Amendment 9).

\section{Proposed Amendment 7}

When people go to their polling places in November 2008, they will see information on the amendment, references to the portion of the constitution that will be altered, sponsor of the amendment, the ballot title, and the ballot summary. The information for Amendment 7 will be similar or identical to the following and the ballot title and ballot summary are direct quotes:

Proposed Constitutional Amendment No. 7: ARTICLE I, SECTION 3 (Taxation and Budget Reform Commission)

\section{Ballot Title: RELIGIOUS FREEDOM}

Ballot Summary: Proposing an amendment to the state constitution to provide that an individual or entity may not be barred from participating in any public program because of religion and to delete the prohibition against using revenues from the public treasury directly or indirectly in aid of any church, sect, or religious denomination or in aid of any sectarian institution.

\section{Effect of Amendment 7}

Amendment 7 eliminates the phrase "Article I, Section 3: No revenue of the state or any political subdivision or agency thereof shall ever be taken from the public treasury directly or indirectly in aid of any church, sect, or religious denomination or in aid of any sectarian institution." If voters approve the amendment, that phrase would be replaced with 
the following language: "An individual or entity may not be barred from participating in any public program because of religion."

In effect, the proposed amendment allows the state to spend state funds directly or indirectly to assist and support sectarian institutions. State staff analysis specifically notes that "this measure does not appear to be designed to authorize the Legislature to re-enact a school voucher program." However, some individuals may disagree.

The proposed amendment is centered on the provision in the state constitution to prohibit the use of state funds at church (sectarian) related schools. This is referred to as the "Blaine Amendment" and was adopted in the 1868 Florida Constitution. This is the section repealed from Article I, Section 3. According to state staff analysis, the Blaine Amendment "was used as the basis, by the First District Court of Appeal ... to invalidate the Opportunity Scholarship Program (OSP).” According to state staff analysis, a dissenting opinion in the First District Court of Appeal decision stated that it "would prohibit any religious institution from acting as a government service provider or participating in secular general welfare programs where there is only an incidental benefit to religion" and that "various legislative programs, in addition to Opportunity Scholarships, that eligible persons may utilize at private educational institutions across Florida, including those that are religiously affiliated or operated," might be unconstitutional as well. State staff analysis identified some of those other programs and a partial list includes:

- Florida Bright Futures Scholarship Program

- John M. McKay Scholarships for Students with Disabilities Program

- Florida Private Student Assistance Grant Program

- William L. Boyd, IV, Florida Resident Access Grants

- Florida Postsecondary Student Assistance Grant Program
- Mary McLeod Bethune Scholarship Program

- Critical Teacher Shortage Student Loan Forgiveness Program

- Minority Teacher Education Scholars Program

\section{Impact of Amendment 7}

The impact of the amendment is unknown. Some people claim the amendment is a blatant attempt to take state funding out of public education and transfer funds to private religious institutions. Others claim that, if it were not for private religious educational activities, the state would be spending even more money than it currently is doing. Additionally, others claim elimination of spending state money at private religious schools would further erode the quality of education in the state.

It seems that if the amendment fails, it might be reasonable to assume that private religious organizations would be limited in the types and amounts of government-type services they could provide in the future. It may be unreasonable to assume the dissenting opinion issued in the First District Court of Appeals decision will apply to some of the other programs identified in the staff report. Those other program expenditures might need to be addressed by the court system on individual merits of the expenditures and programs.

Notably, the state stafff analysis indicates that over $70 \%$ of the nation's states have a "Blaine Amendment" type of provision in their respective constitutions. Therefore, if Floridians pass this amendment to the state constitution, Florida will be unlike the majority of states in the country. For greater detail of the legal history associated with the proposed amendment, visit the TBRC website at http://www.floridatbrc.org. Passage or defeat of this amendment will most likely be influenced by people's values, and the importance, merit, and appeal of the issue to individual voters. If passed, the amendment would become effective on January 6, 2009. 


\section{Summary}

Adoption of the constitutional amendment requires a vote in favor of the amendment by a minimum of $60 \%$ of those voting. Additionally, amendments are subject to legal challenges and could possibly be removed from the ballot if successfully challenged.

Voters in Florida have the opportunity to change the state constitution during the 2008 general election. The intent and purpose of the information contained in this fact sheet on Amendment No. 7 is not to tell individuals how to vote. Rather, the fact sheet is provided to help voters become more informed. Informed voters need to be more knowledgeable of the ballot issue on which they are voting than just by reading a ballot title and ballot summary. Ballot titles and summaries do not inform voters in significant detail, nor do they inform voters on policy implications of what a yes or no vote implies. Because informed voters make informed public policy decisions, your challenge as a voter and a citizen is to become informed and then, by casting your ballot, make your values and preferences known.

\section{References}

Florida Department of State, Division of Elections. 2008. Initiatives / Amendments / Revisions. Division of Elections, Florida Department of State, Tallahassee, FL (May).

http://election.dos.state.fl.us/initiatives/ initiativelist.asp

Florida Taxation and Budget Reform Commission. 2008. A resolution proposing an amendment to Section 3 of Article I of the State Constitution. TBRC, Tallahassee, FL (May). http://www.floridatbrc.org/pdf/CP20E1Final2.pdf

Florida Taxation and Budget Reform Commission. 2008. Staff Analysis and Economic Impact Statement. TBRC, Tallahassee, FL (May). http://www.floridatbrc.org/pdf/

CSforCP20AnalysisTBRC.pdf

Florida Taxation and Budget Reform Commission. 2008. Transmittal letter. TBRC,
Tallahassee, FL (May).

http://www.floridatbrc.org/pdf/

CPTransmittalLetter.pdf 